that it may be either turned to account or shown to be erroneous. If there is even a remote possibility of its truth it would seem worth while for one or more of the Colonial Governments to have borings made in order to test it.

F. T. MOTT

Birstal Hill, Leicester, May 5

\section{The Glacial Blocks of Zinal}

MAY I through your columns express a hope that other qualified observers will volunteer to take charge of work such as I propose to do this summer as my share?

This is to mark the position of large blocks of stone on the glacier of Zinal. You will, I hope, receive the report of my friend, Prof, F. A. Forel, upon periodical variations of glaciers. Therein are sketched some of the existing data. I have for years much wished to organise a simultaneous action. With a Galton's pocket altazimuth, a pot of paint, and the superb map on the scale of $5 \frac{1}{500}$ of the Swiss Alpine Club (Sheet III. of the Valais du Sud), it will be a pleasant and not a difficult task to lay down a few good triangles, and to paint a letter and indication of bearings of stones along and athwart the great glacier, with which I am well acquainted. The Swiss Alpine Club has erected a hut at I.es Mountets, which, at about $95^{\circ} 00$ feet above sea-level, will form a capital base of operations. The preeminently grand scenery would itself reward the short sojourn necessary for our purpose. To secure uniformity of action and registration I propose that we should place ourselves in communication with M. F. A. Forel. I shall be very glad to hear from gentlemen-at this address up to the end of June, and then at the Hôtel d'Anniviers, Vissoie sur Sierre, Canton Valais, the most comfortable quarters in the Val d'Anniviers, about 4000 feet above sea-level, three hours' and a half drive from Sierre rallway station.

I would suggest, as good head-quarters and interesting fields of observation: (I) the hotel at the Riffelberg, with the Gorner and Findelen glaciers ; (2) the hotel at Saas in Grund, with the Fée and other-large glaciers in the Saas-Thal; (3) the hotel at the Maltmark See, with the Allalin and Schwartzberg glaciers; and (4) Macagnaga as a southern station. I myself, also, ask for personal assistance.

Villa Chessex, Veytaux-Chillon, Canton Vaud, Switzerland, May 3

\section{THE FRENCH ASSOCIATION FOR THE} ADVANCEMENT OF SCIENCE AT ALGIERS 1 III.

THE main result of the Algiers Congress has undoubtedly been the acquisition of a considerable amount of matter tending to the development of the great French colony, while at the same time it has been the means of making hundreds of Frenchmen well acquainted with the principal features-physical, geographical, and political-of a country which they knew previously only by name. The general results, as far as universal science is concerned, have been slight, but we cannot regard the Congress as less than a success. It is as if the French had said to the world of science, "Come and see this undeveloped country, and help us to apply each and all of the sciences to its special requirements, to aid us in a more perfect colonisation." The work has been nobly initiated by the French. It is probable that not less than a hundred millions sterling have been expended in the country. The roads and bridges, and telegraph and postal systems are perfect. Everywhere you find evidences of complete organisation. Every small village has its mayor and council; its post-office and diligence service; its water supply and sanitary arrangements ; its groves of eucalyptus-trees and trimly-planted streets. Let us take one example-that of Bordj-Menaïel, a village to the east of Algiers, which we visited in the course of an excursion. Twenty-three years ago Bordj-Menaïel was made a centre of colonisation, and 1718 hectares of land were distributed among the first colonists. The total superficies of the commune is 4200 hectares, and it contains a population of 837 , of whom 659 are Europeans

2 Continued from vol, xxiii, p. 607 . and 178 indigenous races. Situated at a distance of 70 kilometres from Algiers and 38 from Dellys, it is traversed by the main departmental road passing to Eastern Algeria. It stands in the midst of a highly fertile alluvial plain, 28 metres above the sea, and is watered by the Isser. This commune possesses the following municipal officers: mayor, deputy-mayor, justice of the peace, sheriff's officer, receiver of "contributions diverses," a recorder of the census, a manager of ponts et chaussées, a departmental business agent, a bureau of posts and telegraphs, a "médécin de colonisation," a midwife, and a pharmacien. Its spiritual and intellectual wants are provided for by a curé and two schools. Since 1873 a brigade of gendarmerie has been stationed in the village. The organisation appears excessively elaborated for so small a population; but we must remember how doubly necessary such arrangements become in a new colony, which without sufficient proofs of the strong arm of the law would speedily become lawless, and without the benefit of welldirected and properly enforced municipal arrangements would form an ill-regulated and degenerating community. The bureaucracy evidently enters largely into the French system of colonisation.

At the present moment a project is before the Chamber for the completion of the colonisation of Algeria by the creation of 300 new villages, which, like BordjMenaïel and the existing villages, are to be built and thoroughly organised before colonists are invited to accept the grant of land in the commune and take up their abode in the village. Such of the existing villages as we saw were of one and the same type: the church and water-supply in a central square, from which two or more streets proceeded; the mairie, a few shops, one or more inns, and a post-office. In some villages-Palestro, for example, many of the inhabitants of which were massacred by the Kabyles so recently as 1871 -there was a large space, surrounded by a high wall furnished with loopholes, in which the inhabitants could take refuge in the event of a sudden descent of the natives. Many of the colonists are Alsatians or Lorrainers who emigrated at the close of the Franco-Prussian war. They all appeared happy and contented, and their farms and gardens were flourishing. Their worst enemies are drought and fever; the former is being provided against by new systems of irrigation, and the latter by the planting of thousands of eucalyptus-trees. At Blidah we found a perfect example of the most developed system of irrigation. A ready supply of water is obtained during many months of the year from the mountains, and this is led by small brick-lined watercourses through the gardens. A main watercourse passes a line of houses, the garden walls of which are furnished with small trap-doors by which at any time a portion of the stream can be diverted into the garden. Of course rain is always looked for with great anxiety, specially between the months of May and September, when the grain crops are wholly dependent upon it. In the south of Algeria there exist at this moment places where no rain has fallen for six years, and of course any attempt at cultivation is here impossible.

Towards the end of the Congress several of the sections showed greater vitality than at the commencement. In the section of Mathematics there was for the first time a fair show of papers, for the most part devoted to pure geometry. The foreign mathematicians-Leguine of Odessa, Oltramare of Geneva, and Fiedler of Zürichcontributed their quota. M. Trépied brought forward a project for the construction of an observatory at Algiers. M. Picquet has been elected president of this section for next year. In the section devoted to Civil Engineering the most important papers were by Col. Fourchault on defensive villages, and by $M$. Trémaux on irrigation. M. Gobin is president for next year. In the Physical section papers were read by M. Gaussen on photometric photo-
graphy, and by Prof. Tacchini on the solar protuberances. 
There was no paper of special interest in the Chemical section, of which M. Grimaux is president for 1882 . The section of Meteorology was very active at the last, and supplied some interesting papers on the meteorology of Asia, of the Sahara, and of the district between the Atlas and the Cevennes; also on meteorological instrumentsthermographs and anemographs, and registering barometers. MM. Denza and Tacchini among the foreigners contributed largely to this section. M. Fines is the president for I882. The Geological section had no communications of general or special interest. Professors von Szabo of Buda-Pesth and Villanova of Madrid both contributed papers, and an interesting communication was made by M. Fusch (who is president of the section next year), on the lead and iron mines of Tunis, and the copper mines of the Petite Kabylie, a district to the east of Algiers. The Botanical section announced only two papers of very limited interest for the last day but one of the Congress, and it did not meet at all on the last day. M. Ed. Bureau is president for 1882 . The sections of Zoology and Zootechny also showed signs of languishing. On the other hand the section of Anthropology exhibited the greatest vigour from first to last, and on the last day of the Congress no less than sixteen papers, many of them of great local interest, were announced. Among these we may specially mention observations on the Kabyles of the Djurdjura, and on the Tziganes; on the Romans in Africa, and the Berber migration; on the civil, political, and religious institutions of the Jews; and on craniometrical studie; in the oasis of Biskra. A prehistoric map of the north of Africa was discussed by $M$. Cartailhac. Anthropology is one of the sciences which has benefited most by the Algerian Congress. M. Henri Martin is president for 1882 .

The interest in the Medical section continued to the last. We have before had occasion to remark that the Congress to a great extent was a medical réunion, and more than one-fourth of the members were medical men. Seventeen papers were announced for the last day of the session, and fourteen had been read the day before. The most interesting to the general non-medical members were on the epidemics of Algiers, on acclimatisation, and on the climite of Algiers as regards its influence on consumptive patients. Dr. Azam of Bordeaux is the president for 1882. The success of this section has been complete ; a large number of very valuable papers have been communicated, and the attendance has always been large. The final papers communicated to the section of Agronomy related mainly to the development of the agriculture of Algiers : on the cultivation of cereals and of sorghum; on the rearing of cattle; on agricultural railways; and on watercourses. M. Dubort is president for I882. The section of Geography was also mainly devoted to Algerian questions: the Trans-Saharian Railway; the geodesy and topography of North Africa; maps and geographical vocabulary. The section of Political Economy devoted its last hours to the dominant subject throughout - the colonisation of Algeria, the treatment of the indigenous races, and the peopling of the Sahara. Finally the section of Pedagogy visited the principal schools of the city, and collected as much information as possible concerning the methods of instruction.

At the commencement of the Congress the members were presented with a volume entitled "Notices Scientifiques, Historiques, et Économiques sur Alger et l'Algérie." The second volume is to be ready before the end of this month. The work is compiled by twenty-one residents in Algeria, each one very competent to discuss the subject of his contribution. Thus the geography is described by the president of the Algerian Geographical Society, the general administration by the secretary of the Council of Government, and the history by the Director of the École supérieure des Lettres. The whole constitutes the most complete and exhaustive history of
Algeria which exists. Starting with the geography, hydrography, and climatology of the country, an able discussion of its complex meteorology follows. Statistics are given of the barometric pressure, mean temperature, hygrometry, winds and atmospheric currents, electricity, rain, evaporation, \&c. There are forty meteorological stations in the country, extending from Mogador in Marocco, to Sfax in Tunis. A daily bulletin has been issued since 1875 , and it is distributed over thirteen points on the coast. The very interesting geology and mineralogy of the country forms an article by M. Pomel, from which we learn that copper, argentiferous lead, zinc, iron, building-stones, and silt are profitably mined. About 3500 miners are employed, more than half of them finding occupation in the province of Constantine. The succeeding articles treat of botany, zoology, and anthropology. The major part of the indigenous population consists of two ethnic groups: on the one hand the Arabs, nomad tribes, shepherds, with a patriarchal organisation, and with warlike and religious feudality (féodalité guerrière et féodalité religieuse); on the other the Kabyles, cultivators of the soil, non-nomadic, and with a social organisation which is democratic and communalistic.

An article of much interest, by Dr. Liautaud, treats of the colonisation and peopling of Algeria. We have no space to give even an outline of its contents, but we commend it to every one interested in the present and future of the colony. It is followed by articles on the actual state of agriculture ; industry and commerce, public works, the financial system, and the Algerian budgets. Then a general survey of the history of Northern Africa is given by M. Masqueray; archæology by M. MacCarthy; the general administration by M. Dimier; judicial organisation by M. Fau, Advocate-General of Algiers, and taxes and imposts by M. D'Aufresne.

We will glance for a moment at some of the statistics connected with public works and education. When the French took possession of Algiers in 1838 they found a tabula rasa as regards public works. In 1843 they set on foot the drainage of the Mitidja; between 1840 and 1846 ports were constructed, and lighthouses placed along the coast, and great systems of excellent roads were inaugurated; in 1857 railways were commenced. Forty-five lighthouses are now in operation, and there are seven ports. In 1830 the imports amounted to a value of $5,000,000$ francs, and the exports to $I, 500,000$ francs; while in 1879 the values were respectively $272,126,102$ francs and $151,918,421$ francs. There are 10,506 kilometres of roads and 1282 kilometres of railways. There are now about 600 agricultural villages dispersed through the three provinces of Algiers, Oran, and Constantine.

As regards public instruction, higher instruction is given in four schools, which no doubt will soon be united into a university: law, medicine, letters, and science. Secondary education is provided by a Lycée in Algiers, ten communal schools, and three free schools. The former contain 3405 pupils, among whom there are $365 \mathrm{Jews}$, and 272 Mussulmans. The number of primary schools, including Arabic, Kabylic, and Arab-French schools is 703 , in which are educated no less than 53,803 pupils28,803 boys, and 24,5 or girls. The boys consist of I I,639 French, 7336 foreigners, 7408 Jews, and 2420 Mussulmans.

On April 20 the various excursions commenced : eastward to the confines of Tunis, southward to the Sahara, and westward to the boundaries of Marosco. We have not space to tell how we went into the country of the indigenes-the Kabyles who were driven into the mountains when the Arabs first took possession of the landhow they met us headed by their chiefs, and conducted us, with accompaniments of barbaric music, and discharges of guns to awaken the echoes, through the magnificent gorges of Palestro; and how on the following morning 
we breakfasted with them in one of the most picturesque spots imaginable, and finally how we realised with difficulty that we were only four days' journey from London, while breakfasting, under a bower of carouba branches, off sheep roasted whole over hot ashes placed in holes in the earth, manipulated with hunting-knives and without forks, flat circular cakes of Kabyle bread serving us for plates, and gigantic wooden bowls of kous-kous as a second course.

The amicable attitude of these once savage aborigines seemed to us to re-echo the key-note of the Algiers meeting of the French Association; to proclaim loudly and with no uncertain sound that the "conquête pacifique de l'Afrique septentrionale par les Français" has indeed become an accomplished fact.

G. F. RODWELL

\section{ELECTRIC LIGHTING}

II.

THE second district of the City which has been illuminated by electricity is that embracing Blackfriars Bridge, upon which there are seven lamps; Bridge Street, in which there are four lamps, Ludgate Circus taking three lamps ; Ludgate Hill four lamps; north side of St. Paul's six lamps; and Cheapside, as far as King Street, eight lamps; thirty-two lamps in all, replacing 150 gas lamps; and moreover, all these lamps are fixed upon one circuit, which is operated practically by only one machine, and that fixed more than a mile away, at the manufactory of the Brush Company in York Road, Lambeth. The total length of this circuit is over 20,000 feet. It consists of a copper cable made up of seven best copper wires surrounded with a thick layer of guttapercha protected externally with tape that has been well tarred. This wire gives a total resistance of 7.5 ohms. and is protected by iron pipes like the Siemens method, and laid on the principle so well known in telegraphy. The dynamo-machine is of the familiar Brush form, and at present there are two machines of the size known as No. 7 cabled up in series, but forming practically only one machine. These two machines are intended to be replaced by one dynamo-machine, which, at a velocity of 800 revolutions, and worked by 32 indicated horse-power, will maintain forty lamps burning. The main feature of the Brush system is its simplicity, one machine working a number of lights, and those who visit the engine-room of Messrs. Siemens, and then that of the Brush Company, cannot help being struck by the immense difference in the contrast between the two. In Siemens' engineroom one feels in the midst of a whirling cotton manufactory; at the Brush works one sees nothing but a single engine working a single machine quietly and without fuss or flurry.

At present a Galloway engine is used by the Brush Company, but when the large 40-light dynamo-machine is set to work a Brotherhood 3-cylinder engine of 32-horse power will be used. These engines are admirably adapted for electric light purposes; they are bolted on to the same frame as the dynamo-machine, and give a compactness and solidity to the whole that is very striking.

The Brush lamps differ but very little from the generality of arc lamps. The carbons are maintained apart by what is known as a "sucking" coil; and the lamp possesses one or two very ingenious designs to shunt it out of circuit when anything fails and to shunt it in when all is in order. It is a kind of duplex lamp, supplied with a double set of carbons, each of which burns for eight hours, the total illuminating durability of the lamp being therefore sixteen hours. These lamps are fixed upon the ordinary lamp-posts, which have been raised $2 \frac{1}{2}$ feet higher than usual, so as to maintain the lamp i6 feet from the ground. They are surmounted by very ugly x Continued from p. 7 . roofs that are neither covers nor reflectors, and the mode in which these lamp-posts have been utilised is the least commendable feature of this system. Indeed the Company might have made much more of their facilities. Compared with the tall posts in the remainder of Cheapside they make an unfavourable impression. The globes that embrace the light are too small, and the Company itself seems not to have arrived at the proper decision as to the best quality of globe to use, for in some places the lamps have clear globes, in others ground-glass, and in others opal globes, made, we believe, by Mr. Frederick Siemens of Dresden.

It cannot be said that the mode of illumination adopted by the Brush Company is perfect at present. The theory of the proper distribution of the light has been neglected. The lamps are scattered about in an irregular manner that is quite offensive to the eye, and though the effect of each lamp is certainly brilliant, the effect of the whole is rather displeasing. It is very wonderful that so much light should be produced from a point so far, and there is no doubt that the public mind has been captivated by the brilliancy of the lamps. The scientific eye however sees room for improvement, and it is hoped for the sake of the success of the experiment that the Brush Company will be guided by the experience of disinterested persons. The great merit of their system is the simplicity of the machinery employed, as well as the brilliancy of the light, but occasionally the lights are subject to great want of steadiness, and it is much feared, with the quality of the cable they have used and the enormous electromotive force, that the usual faults accompanying underground wires will develop themselves rather largely. In fact, two very serious breaksdown have already occurred, and they are about to replace their conductor by a better one. They will have to pay dearly for their neglect of common experience.

So far the experiment has shown that the practical lighting of streets by electricity is not only feasible but practicable. Moonlight has certainly been thrown into the shade, for the streets of the City are better illuminated by electricity than by fair Luna. It is quite possible to read a letter or to see one's watch at any point in King William Street. Indeed the smallest object can be seen anywhere, even in the middle of the road. Running-over has been rendered impossible.

The outside districts not specially favoured are clammering for electric lighting, but much has yet to be learnt before the experiment can be determined as final. For instance, we have the Lontin system to be tried, and we should certainly like to see that most energetic and successful engineer, Mr. Crompton, test his system in the London streets. Incandescert lamps are looking up and deserve a trial.

The best mode of distributing light has not yet been settled.

It would seem that a compromise between the centralised system of Siemens and the distributed system of the Brush Company is that needed to solve the problem of proper street illumination. But instead of carrying lamps irregularly down streets on hideous lamp-posts it would almost seem that the ancient defunct mode of swinging lamps across streets from housetops would be a better mode of illuminating streets. Take, for instance, Regent Street. If that street had suspended above it, at the height of 40 feet or 50 feet and at about every 100 yards, a Brush lamp fitted on the top of a graceful iron arch, or suspended on wire ropes between the tops of the houses, nothing could possibly be greater than the effect. Light arches thrown across the street might even be a convenient mode of suspending the wires forming the circuits, for overhead wires have a considerable advantage over underground wires in this, that they cool more rapidly and allow more electricity in consequence to pass through. More than that, they require no insulation, and the money thrown into their insulation could be thrown 